\title{
Students Learn Better Through Reasoning by Analogy, But How? : A Comparative Approach
}

\author{
Ayse Kutlu \\ A PhD candidate of European University, \\ Tirana, Albania \\ email: adilekutlu@hotmail.com \\ Adil Kutlu \\ A lecturer at Beder University, a PhD candidate of European University, \\ Tirana, Albania \\ email: kutluadil@hotmail.com
}

Doi:10.5901/jesr.2014.v4n2p30

\section{Abstract}

This study aims to identify the factors that make students' learning better in educational environment through a case-based reasoning learning. The students are learning well with the help of similarities between previously distinct problems. It is considered as reasoning by analogy. The qualitative approach was used in this study to clarify he factors for understanding reasoning in relation with educational learning. This study gives the importance of reasoning by analogy and making the learning process interesting and also making the learning a success through comparing the explanations and views of Paul Thagard and the Prophet Muhammad. Actually, the teacher is considered as facilitator and facilitates the learning process for better examples and instructions to help the students get the points. The necessary data for the study were collected from the written views of Paul Thagard and the Prophet Muhammad's approach in this regard. As the limitation of present study, we can say that we could not make any questionnaire or interviews with any professors and lecturers for increasing the reliability and validity. The results demonstrate that the teachers should use reasoning by analogy in learning process to make students interested and better learned for fruitful outcomes overall. Therefore, this positive approach will make students understand and learn easily and also increase the students' motivation for successful learning outcomes.

Keywords: Analogy, Reasoning, Learning process, Case-based learning, Outcome.

\section{Introduction}

Man who is in the process of learning from the moment he was born learns about everything he has needed and wondered about in his lifetime. There is a direct relationship between man, the most precious being who has the ability to learn, and the concept of learning. Every other living being apart from human comes to the world with the equipment necessary for their lives whereas man acquires these abilities and skills later. This being whose effort to learn never ends maintains this process which he begins in family environment also in school, streets and in the circle of friends. (Keyifli, 2012)

The information needed by an individual and the methods by which these can be taught have always occupied people's minds. It cannot be denied that the learning method preferred while meeting the needs of individuals for learning with the system of formal and non-formal education influences the positive behaviors expected from the individual. Many teaching methods such as case study, discussion method, explaining method, question answer, problem solving, displaying and practicing and trip and observation have been developed in order to make this aim real and achieve the quality expected from education.

This writing emphasizes on the teaching method of compare and contrast, which is known as analogy as well and developed by Paul Thagard, and it will relate the past to these days by giving examples of how Muhammad the Prophet of Islam (P.B.U.H.) used this method effectively while explaining the orders and prohibitions of Allah to those who believed in Him and educating them in the sense of morality. Also, this strives for giving new ideas to the teachers.

Teaching, which is as old as the history of prophecy, started with Adam (P.B.U.H), the first human and prophet, and continued with the other prophets. Adam the prophet and all the subsequent prophets did their teaching duties 
according to the characteristic features of their tribes. The most important duty of the prophets is actually tablig (announce) and tabyin which means to explain the announced truths. (Nahl: 44)

\section{Literature Review}

Learning can be defined as lasting behavioral changes that occur in the natural development of an individual as a result of his interactions with the environment. It is part of the natural development of the individual. (Kaya, et, al., 2013) \& (Witrock, 1977) approaches to the concept of learning from a different angle: a behavioral change in "meaning, knowledge, abilities, attitudes "dependent on duration. Mayer (1987), Woolfolk (1990) and Gayna (1985); consider it as a change that offers a certain permanence. Learning is not formed as a result of other factors such as growth,sleep, medicine etc and is not temporary and there is a period of time of permanence.(Şendurur, 2001). According to the constructivist theory it can be defined as an active process of interpretation in accordance with previously acquired knowledge and experience. (Kesercioğlu,2004).

These changes in behavior dependent on duration result in certain methods. According to the scientific method, it is the entire amount of the studies that are conducted regularly to understand and emphasize, interpret and offer solutions to the issues and problems that arise and may arise in the environments where we live.

During the education process, a lot of teaching methods based on learning theories have been developed. Learning methods can be listed in the following way; Case narrative, discussion method, description method, questions and answers, solving the problems, demonstration and practice, observation. (Ünal, T. Y). Method: Procedure. In science, a plan to access a certain result, the followed paths.

The method of this path is the path that leads to the purpose that is way it should be well-thought, analyzed and well planned. Otherwise the teaching job would be too complex like seeking a way out of the maze. (Ünal, T. Y).

\section{Discussion}

One of the effective methods that will allow the individual to learn the essential, practical conveyor is the analogy method. Analogy as a teaching method is seen in the teaching methods of Prophet Muhammad (P.B.U.H). In this study, we compare the opinions of Paul Thagard and the approaches of the Prophet Muhammad (P.B.U.H) and the prophet's exemplary applications as a descriptive manner.

Before learning the analogy method learning strategies can be classified like the followings: Repetition, meaning, organization, comprehension monitoring, emotional strategies. Elaboration strategy is the activity of learning by integrating the new and knowledge that existed in the memory for a long time. Analogy is a method that is located within the signification strategy.

Analogy method: (analogy, comparison) Analogy is the method of explaining in different ways by giving as an example an event. (Dinçer, T. Y). Analogies are depictions of understanding of new knowledge. Ausubel (1969), Gagne \& Briggs (1974) in their study indicate that association of the prior knowledge and the new one will make learning more meaningful.

The information of the individual's past in the literature is accepted as analogous while the new information is accepted as the goal. The findings obtained as a result of the studies support that the analogies increases the students' interest, curiosity and motivation (Keller, 1983), it supports conceptual change (Dagher, 1994) and it is an effective means of establishing relationships between concepts (Stepich \& Newby, 1988) \& (Kesercioğlu, 2004).

When this method is used correctly and has achieved its goal it stays for a long time in the individual's long-time memory. Teachers use analogies to simplify concepts and less familiar systems, and to embody abstract concepts with concepts that are more familiar.

One of the modern representatives of this method Duit (1991) gives as an example the relationship of the objects when passing from source information to new information. To stimulate his theory he gives as an example the likeness of atom to solar system. According to Holyoak the new events that will be learned, can be compared to the 'source information' by installing relationships and building bridges. At the same time method is a tool to create a basis for discussion and to solve the problems. (Ekici, 2007).

With analogy as the method of learning, some considerations are to be taken into account. The goal should be well established, and a known analogy should be used for the unknown notions. If the target is abstract being or concept a concrete analogy should be used, a person's past should not be underestimated. Mintzes and his colleagues (1997) together with TWA model have generated six models of analogies such as: General analogy, bridge analogy, multiple 
analogies, anecdotal analogies, case-based reasoning analogies and student generated analogy. (Kesercioğlu, 2004).

It is the most appropriate method in students understanding of abstract concepts. Explaining one event with their own expressions and internalizing it provides advantages. While considering the students as active this way also develops the creativity features. The knowledge except of the classical way of learning are learned with other kind of method. While drawing attention to the topic it also provides motivation. Establishing one connection between scientific language and everyday language facilitates learning (Yoldaş, T. Y).

The rise of man and the society they make up, their progress and their coming to a certain level is based on the education of the individual and society. (Yoldaş, T. Y). We know that monotheistic religions together with the first man have transmitted to us the messages of Allah.

It is seen that these divine orders that come to prophets as revelations in the form of words and behavior are later on turned into practices. When prophets are considered from a wide spectrum as leaders or guides they have not only been an example with their behaviors but they also have been leaders in an invention.

They have not only had the duty of warning people but also pioneered in some of the greatest inventions that would shed light to civilizations. For instance Prophet Noah with the art of carpentry gave the first ship gifts to humanity, prophet Joseph made the first clock, Prophet David with treatment of iron and armor making and Prophet Idris with finding of the needle has contributed to the art of tailoring. In this sense, prophets have been instrumental in the progress of civilization because beside dealing with world affairs, they have also taught people professions that will be useful to humanity.(Bayraktar,1984).

In order to fulfill their duties they are seen to have successfully completed them by acting according to the orbit of revelation. In the name of 'shaping' their community we witness in each prophet certain methods according to the addressee and individuals they are to speak to. Contact Person recognition, drawing attention of the audience with interesting questions, questions and answers, repetition, explanation by giving examples are some of the methods. (Soysaldı, T. Y).

Information about the social, economic, cultural religious background and also how to approach to the addressed, what methods will be given, to what amounts is important when explaining people religion. If guidance and their mission of showing the true path was done without taking into consideration these conditions it would have been worthless.(Yargıcı,1998) Heavenly books have benefited from the similar methods that prophets have followed. In particular in Matthew's Bible in the narrative part about God and the afterlife obvious analogies are encountered, meanwhile we can frequently see them in the Qur'an.

The meaning of term, the only thing that doesn't manifest in reality is Tezka, preacher, incentives, Zecca, the signs, an approval transaction, approximates to man's mind what is meant, noticeable meaning, are some of the examples that are meant in Quran. (Altun, 2006) When we compare good and bad," Good is always likened to a tree that has strong roots, high branches and always gives fruits" and bad word "is likened to a tree that its body is uprooted from ground, and there is no place where to hold". (Ibrahim, 24/26).

If we would give some examples from the analogies in Bible, the concept of God is used in their daily life for the cases analogy that is done. " No one can serve (worship) two masters. He will love one and will hate the other or he will adhere one and despise the other. You can't worship both God and money. For this reason in telling you 'don't worry for "your food and drink" and "your clothes" for your body. Isn't soul more important than food and body more important than body? (Matta 6:24-25).

When we have a look at holy books such as Quran we come across to many teaching methods verses. We have the unlawfulness of alcohol with the gradualist method. (Nahl 67 \& Nisa 43 \& Maide 90, 91 \& Bakara 219), when they asked for the owner of the asset is used question and answer method. . (En'am 12). It has remembered the history of previews prophets remind these reasons and give lessons. (Yusuf 111), the facts of hereafter life are eternal life. (Ankebut 64) \& (Bayraktar, 1984).

Prophets have taken into account the structure and location of their community's cultural, economic, sociological structures when they communiqué to them. To make the issues that they preached easier to understand and permanent in their minds there are possible enabled methods. And Muhammad (pbuh) that is the descriptive of the Quran has used the same methods that are used in Quran in his preachers. In Quran and Hadith are used similar methods and the aim is the same.

"The real wrestler is not the one that his back doesn't come to the ground and beats his opponents in wrestling but the one who dominates his soul when he is angry. (Buhari, Edeb 102; Müslim, Birr, 106) In this hadith the importance patience is expressed by introducing two opposite things. 
"Allah is pleased with the repentanance of his servant as much as man is pleased when he has lost hic camel in desert and he finds it again" (Buhari,Deavat4;Müslim,Tevbe 1) The importance of repentance and Istiğfar; has been described with the similarities of these two events .

" Some of the people that will enter Paradise their heart are like bird". (Müslim, cennet27) compering a belivers heart with a bird is illustrated method for the consideration gives trust in god. Believers In loving each-other, protecting each-other showing compassion and mercy for each-other are similar to the functioning of the body.

Because, if a limb is sick all other limbs will suffer with insomnia and fever with it. (Buhari ,salat88;Müsslim,Birr 65) Solidarity with each other Prophet Muhammad (P.B.U.H) has been likened to the functioning of the body, has established similarity between two states. For the same topic in another hadith Buhari likened as interlocking parts of a building, to be understood the topic he has showed it by interlocking his fingers. .(Buhari, Salat. 88 \& Müslim, Birr. 65)

\section{Conclusion}

People know what they are coming to life as different. But during all the life he shows effort and struggle. If we would express it with other words "he learns from the cradle to the grave". This learning sometimes happens in a systematic way within school atmosphere and sometimes during the everyday life.

To progress and develop the society and to move on and go forward on the steps of civilization should not be underestimated the role of holy books and the prophets. In Holy Texts and in the words of Prophets by taking in consideration the society's understanding, the economic, cultural and social situation there is explained with different kind of methods.

Between these methods the method of analogy especially abstract concepts, facts and events are used frequently for understanding. This method is more evident in the words of the Prophet Muhammad.

He has tried to explain topics and advices related to morality, repentance, solidarity, patience, confidence, compassion, etc. that some people would find them difficult to understand by giving examples and comparing with their own life style.

The same method has been used often recently to explain the science. In learning situation this learning is realized by comparing the individual's past experiences with already known cases and the cases that are similar to the new topic that will be learned.

In the study, this method is proofed to have benefits such as facilitating learning and that the learned knowledge would be more memorable, the students would be more active and creative, it would improve thinking in one other way and would establish one connection between science language and everyday language.

As a result we may say that the analogical method is one of the most important methods in effective learning and this method together with the usage of the prophets and Holy books is paralleled used nowadays as one teaching method.

\section{References}

Keyifli,Ş. (2012). Ihtiyaç analizli öğrenme modeli.Günebakış. Retrieved on: 11/04/2014. From: http://www.manisagunebakis. com/index.php ?pages=yazarg\&yazarid=3\&yaziid=43,

Kaya, S. K, \& Selvi, H, \& Deveci, O. C, \& Adıgüzel. (2013). Eğitim Biliminde Yenilikler,T.C.Anadolu Üniversitesi Yayını. Retrieved on: 08/04/2014. From: http://eogrenme.anadolu.edu.tr/eKitap/SOB202U.pdf.

Şendurur,Y. (2001). Keman Eğititmde Etkili Öğrenme-Öğretme Yöntemleri.G.Ü.Gazi Eğitim Fakültesi Dergisi.21.3:145-155. Retrieved on: 07/04/2014. From: http://www.gefad.gazi.edu.tr

Kesercioğlu, T. H, \& Yılmaz. P, \& Huyugüzel. B, \& Çavaş. (2004). Illköğretim Fen Bilgisi Öğretiminde Analojilerin Kullanımı.Ege Eğitim Dergisi.5:35-44. Retrieved on: 05/04/2014. From: dergipark.ulakbim.gov.tr/egeefd/article

Ünal,S.Bilimsel Yöntem.(t.y). Retrieved on: 05/04/2014. From: iys.inonu.edu.tr/webpanel/dosyalar.

Ergun, Mustafa.A,Özdaş. Öğretim Illke Ve Metodları.Türkiye Sanal Eğitim Bilimleri Kütüphanesi. Retrieved on: 03/04/2014. From: http://www.egitim.aku.edu.tr

Türk Dil Kurumu Sözlüğ̈ü.(t.y). Retrieved on: 04/04/2014. From: http://wwww.tdk.gov.tr.

Ergun,Mustafa.A,Özdaş.Öğretim IIlke Ve Metodları.Türkiye Sanal Eğitim Bilimleri Kütüphanesi. Retrieved on: 03/04/2014. From: http://www.egitim.aku.edu.tr

Dinçer,S. Bilgisayar ve Teknolojileri Öğreniminde Analoji Yönteminin Yararları ve Yöntemleri. Retrieved from: ab.org.tr/ab05/ tammetin/168.doc

Kesercioğlu,T.H, \& Yılmaz.P,Huyugüzel.B,Çavaş.(2004). İlköğretim Fen Bilgisi Öğretiminde Analojilerin Kullanımı.Ege Eğitim 
Dergisi.5:35-44 Retrieved on: 05/04/2014. From: dergipark.ulakbim.gov.tr/egeefd/article.

Ekici,E.F, \& Ekici.F,Aydın.(2007). Fen Bilgisi Dersinde Benzeşimlerin Kullanabilirliğine İlişkin Öğretmen Adaylarının Görüşleri ve Örnekleri.Ahi Evran Üniversitesi Kırşehir Eğitim Fakültesi Dergisi.8.1:95-113. Retrieved on: 05/03/2014. From: http: //www.academia.edu.

Kesercioğlu,T.H, \& Yılmaz.P,Huyugüzel.B,Çavaş.(2004). İlköğretim Fen Bilgisi Öğretiminde Analojilerin Kullanımı.Ege Eğitim Dergisi.5:35-44 Retrieved on: 05/04/2014. From: dergipark.ulakbim.gov.tr/egeefd/article.

Yoldaş,C.Analojiler. Retrieved on: 01/04/2014. From: www.pegem.net

Atay,H.İlamda öğretim. Retrieved on: 01/04/2014. From: http://dergiler.ankara.edu.tr/dergiler.

Bayraktar,F.(1984). İslam Eğitimnde Öğretmen Öğrenci Münasebetleri.2. İstanbul.Marmara Üniversitesi İlahiyat Fakültesi Vakfı Yayınları.

Soysaldı, M.Hz Peygamber(s.a.v.)in Toplumu Islahta Tebliğ Metodu.(t.y) Retrieved on: 02/03/2014. From: http://web.firat.edu.tr/msoysaldi.

Yargıcı, A.(1998). Kurani Tebliğ Metodu.Köprü Dergisi.63. Retrieved on: 06/03/2014. From: http://www.koprudergisi.com.

Altun, M. (2006). İslam Eğitim Geleneğinin Temel Kaynaklarında Empatik Yaklaşım.Yayınlamış Doktora Tezi.Anakara.Ankara Üniversitesi SBE.

Bayraktar, F. (1984).İslam Eğitiminde Öğretmen Öğrenci Münasebetleri.2.İstanbul.Marmara Üniversitesi Illahiyat Fakültesi Vakfı Yayınları. 